\title{
METODOLOGY FOR SELECTING THE BEST SUITABLE BOTTLENECK DETECTION METHOD
}

\author{
Eliseu Lima \\ Leonardo Chwif
}

Departamento de Pós Graduaçäo

Escola de Engenharia Mauá, Praça Mauá 1

São Caetano do Sul, 09580-900, BRAZIL

\begin{abstract}
Focusing on process constraints (or bottlenecks) is how companies are improving productivity, decreasing response times. However, a bottleneck is not easily detectable, especially when conventional bottleneck methods are used. This work presents a method, based on simulation, to help the selection of the bottleneck detection method to be applied to a given situation. The methodology extends previous works on the subject, mainly those by Roser, Nakano and Tanaka (2002) and Roser, Nakano and Tanaka (2003). The proposed method was successfully applied to a real bottling process.
\end{abstract}

\section{INTRODUCTION}

The study of bottleneck detection gained attention shortly after the book "The Goal" (Goldratt 1992). The author presented in his book a new vision on how to obtain better process improvement by identifying and acting on processes' bottlenecks, to improve productivity. The central ideal is well known: the bottleneck is the root of system's performance problems. Therefore, improvements in resources rather than bottleneck(s) will not help in achieving better results. But, in real systems, a bottleneck is not so easily detected.

The objective of this work is to present a methodology for selecting the best bottleneck detection method for a given situation. This method was successfully applied to a real bottling process.

This work is organized as follows: section 2 makes a brief conceptualization of the bottleneck types and the main bottleneck detention methods; section 3 discusses the proposed method; section 4 presents a case study; section 5 shows the main results, closing with section 6 , which presents conclusions.

\section{BOTLENECK ANALYSYS}

According to Goldratt (1992), the flow of goods of an entire system is limited by the capacity of different machines; some machines affect the overall system performance more than others. These machines are called
Marcos Ribeiro Pereira Barreto

Departamento de Mecatrônica

Universidade de São Paulo, Av. Prof. Mello Moraes 2231

São Paulo, 05508-900, BRAZIL

bottlenecks. The main bottleneck types can be classified into 3 categories:

- Simple Bottleneck (Grosfeld-Nir 1995),

- Multiple Bottleneck (Aneja and Punnen 1999)

- Shifting Bottleneck (Roser, Nakano, and Tanaka 2002)

Figure 1 shows the basic configuration of these bottleneck types. In Simple Bottleneck there is only one bottleneck machine during the entire period considered. In Multiple Bottlenecks case, there are some bottlenecks, but these bottlenecks are fixed for the entire period considered. For the Shifting Bottleneck situation, there is no single bottleneck for the entire period; the bottleneck is instantly shifting between one station to another.

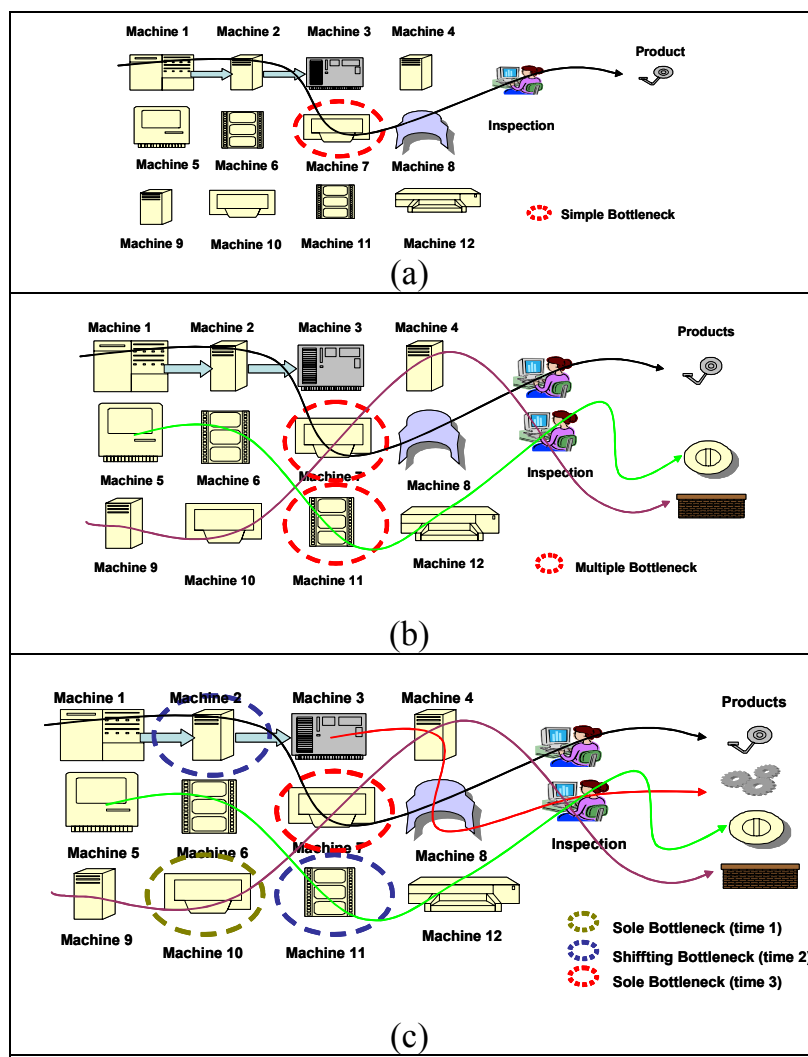

Figure 1: a) Simple Bottleneck, b) Multiple Bottleneck, c) Shifting Bottleneck 
Table 1, which was taken from Roser, Nakano and Tanaka (2003), shows the main characteristics of the Bottleneck Detection Methods.

Table 1: Bottleneck Detection Methods (Source: Roser, Nakano and Tanaka 2003)

\begin{tabular}{|c|c|c|}
\hline Method & Characteristic & $\begin{array}{l}\text { Measure- } \\
\text { ment }\end{array}$ \\
\hline $\begin{array}{l}\text { 1. Utilization } \\
\text { Factor }(\%)\end{array}$ & $\begin{array}{l}\text { The percentage of time that the } \\
\text { production station is working } \\
\text { with regards to the system's } \\
\text { overall time is measured. The } \\
\text { machine with higher utilization } \\
\text { would be the bottleneck. }\end{array}$ & Percentage (\%) \\
\hline $\begin{array}{l}\text { 2. Queue size in } \\
\text { front of machine }\end{array}$ & $\begin{array}{l}\text { The quantity of products in the } \\
\text { queue before the machine } \\
\text { (which will be processed) is } \\
\text { measured. The machine that has } \\
\text { the longest queue should be the } \\
\text { bottleneck. }\end{array}$ & $\begin{array}{l}\text { Quantity of } \\
\text { products }\end{array}$ \\
\hline $\begin{array}{l}\text { 3. Waiting time } \\
\text { in front of the } \\
\text { machine }\end{array}$ & $\begin{array}{l}\text { The same as Queue Size but it is } \\
\text { measured how long a product } \\
\text { will wait in queue to be proc- } \\
\text { essed. }\end{array}$ & Time \\
\hline $\begin{array}{l}\text { 4. Active Period } \\
\text { Method }\end{array}$ & $\begin{array}{l}\text { Two states (active and non ac- } \\
\text { tive) are considered, being } \\
\text { measured the sum of the overall } \\
\text { duration that a machine is in ac- } \\
\text { tive state. The machine with the } \\
\text { highest Active Period is the Bot- } \\
\text { tleneck }\end{array}$ & $\begin{array}{l}\text { Time unit or } \\
\text { percentage of } \\
\text { time }\end{array}$ \\
\hline $\begin{array}{l}\text { 5. Shifting Bot- } \\
\text { tleneck } \\
\text { Method }\end{array}$ & $\begin{array}{l}\text { Sum of the duration (or percent- } \\
\text { age) that one production station } \\
\text { is in the active state without in- } \\
\text { terruption in a period of time. } \\
\text { The time periods in which the } \\
\text { production station is the sole } \\
\text { bottleneck and the time periods } \\
\text { that the production station is a } \\
\text { shifting bottleneck is summed to } \\
\text { find the bottleneck total time. } \\
\text { Although instantly some ma- } \\
\text { chines can be the bottleneck the } \\
\text { one with the highest value will } \\
\text { be the major bottleneck. }\end{array}$ & $\begin{array}{l}\text { Time unit or } \\
\text { percentage of } \\
\text { time }\end{array}$ \\
\hline
\end{tabular}

\section{PROPOSED METHODOLOGY}

The methods shown in Table 1 will not give the same results, which suggest the need for selection criteria. The work of Lima and Chwif (2007) proposes some guidelines for selecting the most suitable method for bottleneck detection. Table 3 summarizes the recommendations on that work. But Lima and Chwif (2007) does not define objectively the concept of "Fluctuation", making the application of the guidelines very subjective, although still useful.

To overcome this issue, based on the article by Tanaka, Nakano and Roser (2002), a numeric indicator to evaluate "Fluctuation" was defined. According to Tanaka, Nakano and Roser (2002), a production station is considered "Sole Bottleneck" only if this station is uniquely responsible to constraint all the system during a given pe- riod; this process will be called "low fluctuation". When there is more than one station concurring at the same time, these stations are a "Shifting Bottleneck" and the sum of the sole plus shifting times during the entire process determine the primary and secondary bottlenecks, as the fluctuation moments. By this definition, systems that possess a high changing frequency of "Soles Bottlenecks" may be considered a process with "high fluctuation".

In order to determine the degree (hi or low) of process fluctuation only two variables are to be considered: the total number of production stations involved and the "Sole Bottleneck Frequency" per station throughout the process. The quotient of these two variables generates a factor that dictates the behavior of fluctuations. Therefore the following equation should be used:

$$
\text { elf }=\frac{\sum \text { station }}{\sum_{n}^{1} \text { frequency }}
$$

where "elf" is the factor that measures fluctuation.

The ELF's reference value of 0.5 was determined by empirical mean; However the main idea of the ELF threshold of 0.5 is the following: if the minimum average frequency for each production station is 2 , this means that it is not a sole bottleneck and probably others production frequency are equal or higher than 2 , therefore there will not be possible to have a sole bottleneck since 2 is the minimum value of frequency. Converting this value to the ELF calculation, this fluctuation generated ELF tending to 0.5, as can be seen at the several examples of table 2 .

Table 2: ELF Set-Point - "Empirical Mean"

\begin{tabular}{|c|c|c|c|}
\hline Station & Example 1 & Example 2 & Example 3 \\
\hline Station1 & 2 & 2 & 2 \\
\hline Station2 & 2 & 2 & 2 \\
\hline Station3 & 2 & 2 & 2 \\
\hline Station4 & 3 & 2 & \\
\hline Station5 & 2 & 2 & \\
\hline Station6 & 2 & 2 & \\
\hline Station7 & 2 & 1 & \\
\hline Station8 & 2 & 2 & \\
\hline Station9 & 2 & 2 & \\
\hline Station10 & 4 & 2 & \\
\hline Station11 & 2 & & \\
\hline Station12 & 2 & & \\
\hline Station13 & 2 & & \\
\hline Station14 & 2 & & \\
\hline Station15 & 2 & & \\
\hline Station16 & 2 & & $\mathbf{2}$ \\
\hline Station17 & 2 & & \\
\hline Station18 & 2 & & \\
\hline Station19 & 2 & & \\
\hline Station20 & 2 & $\mathbf{1 9}$ & \\
\hline Sum Freq & $\mathbf{4 3}$ & $\mathbf{1 9}$ & \\
\hline AVG Freq & $\mathbf{2 , 2}$ & $\mathbf{0 , 5 2 6}$ & \\
\hline ELF & $\mathbf{0 , 4 5}$ & & \\
\hline
\end{tabular}

When ELF is lower that 0.5, the process has high fluctuations, which (from Table 3) suggests the use of the Shift- 
ing Bottleneck method (Table 1, case 5). When ELF is higher that 0.5 , the process has low fluctuations, given room to the use of the other methods cited on Table 1.

Table 3: Bottleneck Detection Recommendation Table

\begin{tabular}{|c|c|c|c|c|c|}
\hline $\begin{array}{l}\text { Method } \\
\text { \#Situa- } \\
\text { tion }\end{array}$ & 1 & 2 & 3 & 4 & 5 \\
\hline $\begin{array}{l}\text { - Low Mix } \\
\text { - Low Sta- } \\
\text { tion Num- } \\
\text { ber- Low } \\
\text { Fluctua- } \\
\text { tion }\end{array}$ & $\begin{array}{c}\text { Rec- } \\
\text { om- } \\
\text { mend } \\
\text { ed }\end{array}$ & $\begin{array}{l}\text { Recom- } \\
\text { mended, } \\
\text { but the } \\
\text { queue } \\
\text { size } \\
\text { should be } \\
\text { infinite }\end{array}$ & $\begin{array}{l}\text { Recom- } \\
\text { mended, } \\
\text { but the } \\
\text { queue } \\
\text { size } \\
\text { should be } \\
\text { infinite }\end{array}$ & $\begin{array}{l}\text { Recom- } \\
\text { mended }\end{array}$ & $\begin{array}{l}\text { Recom- } \\
\text { mended if } \\
\text { other } \\
\text { methods } \\
\text { are not ap- } \\
\text { plicable }\end{array}$ \\
\hline $\begin{array}{l}\text { - Hi Mix - } \\
\text { Low Sta- } \\
\text { tion Num- } \\
\text { ber- Low } \\
\text { Fluctua- } \\
\text { tion }\end{array}$ & $\begin{array}{c}\text { Rec- } \\
\text { om- } \\
\text { mend } \\
\text { ed }\end{array}$ & $\begin{array}{l}\text { Recom- } \\
\text { mended, } \\
\text { but the } \\
\text { queue } \\
\text { size } \\
\text { should be } \\
\text { infinite }\end{array}$ & $\begin{array}{l}\text { Recom- } \\
\text { mended, } \\
\text { but the } \\
\text { queue } \\
\text { size } \\
\text { should be } \\
\text { infinite }\end{array}$ & $\begin{array}{l}\text { Recom- } \\
\text { mended }\end{array}$ & $\begin{array}{l}\text { Recom- } \\
\text { mended if } \\
\text { other } \\
\text { methods } \\
\text { are not ap- } \\
\text { plicable }\end{array}$ \\
\hline $\begin{array}{l}\text { - Low Mix } \\
\text { - Low Sta- } \\
\text { tion Num- } \\
\text { ber - Hi } \\
\text { fluctuation }\end{array}$ & $\begin{array}{c}\text { Low } \\
\text { Rec- } \\
\text { om- } \\
\text { mend } \\
\text { ed }\end{array}$ & $\begin{array}{l}\text { Low re- } \\
\text { com- } \\
\text { mended } \\
\text { (espe- } \\
\text { cially if } \\
\text { queues } \\
\text { are not } \\
\text { infinite) }\end{array}$ & $\begin{array}{l}\text { Low re- } \\
\text { com- } \\
\text { mended } \\
\text { (espe- } \\
\text { cially if } \\
\text { queues } \\
\text { are not } \\
\text { infinite) }\end{array}$ & $\begin{array}{l}\text { Low } \\
\text { Recom- } \\
\text { mended }\end{array}$ & $\begin{array}{l}\text { Recom- } \\
\text { mended }\end{array}$ \\
\hline $\begin{array}{l}\text {-Hi Mix } \\
\text {-Hi Station } \\
\text { Number - } \\
\text { Hi Fluc- } \\
\text { tuation }\end{array}$ & $\begin{array}{l}\text { Low } \\
\text { Rec- } \\
\text { om- } \\
\text { men } \\
\text { ded }\end{array}$ & $\begin{array}{l}\text { Non } \\
\text { Recom- } \\
\text { mended }\end{array}$ & $\begin{array}{c}\text { Non } \\
\text { Recom- } \\
\text { mended }\end{array}$ & $\begin{array}{l}\text { Low } \\
\text { Recom- } \\
\text { mended }\end{array}$ & $\begin{array}{l}\text { Recom- } \\
\text { mended }\end{array}$ \\
\hline
\end{tabular}

\section{CASE STUDY}

The proposed method was applied on a company that produces chemical additives for the automotive industry. The final product is in liquid state and is bottled into plastic recipients. As can be seen from Figure 2, the process comprises two working centers (WC). On the first WC, the "Bottle WC", raw materials (plastic) are transformed into bottles, using blowing plastic machines, and then directed to serigraphy machines, to write the label. The second WC, the "Bottling WC", takes bottles from "Bottle WC", and is responsible for mixing components and filling the bottles.

A simulation model of this process was constructed using Simul8 Simulation Software. With this model, it was possible to determine the frequency of the sole bottleneck shifting during the entire simulated period. The overall process contains 47 stations where the "Sole bottleneck Frequency" was 0 except for two Stations: Blow3 and Blow1. This demonstrates that these two machines are candidates to be considered as bottleneck. The ELF factor is $47 / 2=23.50$. According to the proposed method, this is a case of multiple bottlenecks (with no fluctuation); therefore, Table 3 suggests the use of static methods.

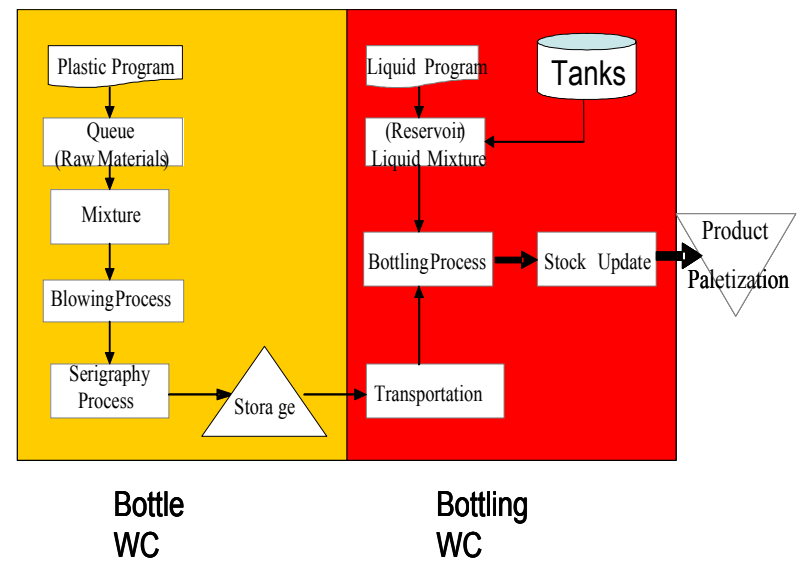

Figure 2: Diagram showing the process for the case study

Changing the point of view may lead to different results. Consider now only the "Bottling WC", which has 20 stations. By making the same analysis as done before, the fluctuation is much higher. Table 4 summarizes the 'Sole Bottleneck Frequency" for each station. The ELF factor for this case is $20 / 131=0.15$. According Table 3 , the best suitable method would be the shifting bottleneck. In order to demonstrate these findings, the next section will apply all the bottleneck methods listed on Table 1 for both situations: the complete model and only for the "Bottling WC".

\section{RESULTS}

Table 5 shows the application of all bottleneck methods for the complete system ("Bottle WC" + "Bottling WC"). The result is the average of 5 replications, each within $\pm 1 \%$ precision (confidence intervals with a $95 \%$ confidence level for the total bottleneck probability). Station Blow1 is the main bottleneck, followed by station "Blow 3". As can be seen from the Table 5, all but queue size method pointed out to the same resource as a bottleneck, whereas queue size method pointed out to the station "Transport5". This anomaly can be caused by the fact the process does not have infinite buffers. Hence, as previously mentioned, the methods based on queue may not be trustworthy.

If Blow1, the main bottleneck, is removed from the analysis, all methods except those based on queues size (methods 2 and 3 ) converges to the same production station, "Blow1". Therefore when dealing with low fluctuation, methods 1,4 and 5 are equally efficient.

The same analysis was performed with the model only for the "Bottling WC"; Table 6 compares again all bottleneck detection methods. In this case, methods 2 and 3 diverge from the others, which indicate the low confidence of these methods, which has been reinforced by the fact that an indicator could not be obtained for some stations. 
Table 4: Sole Bottleneck Changing Frequency for the Bottling WC

\begin{tabular}{|l|c|}
\hline \multicolumn{2}{|c|}{ "Bottling Factory" } \\
\hline Station Name & $\begin{array}{c}\text { Sole Bottleneck Fre- } \\
\text { quency }\end{array}$ \\
\hline Transport 1 & 1 \\
\hline Tank A & 16 \\
\hline Tank B & 5 \\
\hline Promaq_Serac & 14 \\
\hline Transport 2 & 8 \\
\hline Tank F & 58 \\
\hline Adptador3 & 1 \\
\hline Transport 3 & 6 \\
\hline Tank V & 1 \\
\hline P04 & 1 \\
\hline Transport 4 & 1 \\
\hline Transport 5 & 0 \\
\hline Tank O & 1 \\
\hline Tank P & 9 \\
\hline Adptador 2 & 2 \\
\hline Transport 6 & 1 \\
\hline Transport 7 & 3 \\
\hline Transport 8 & 1 \\
\hline Tank H & 1 \\
\hline Transport 9 & $\mathbf{1 3 1}$ \\
\hline & $\mathbf{6 , 5 5}$ \\
\hline Sum Freq & $\mathbf{0 , 1 5 3}$ \\
\hline AVG Freq & \\
\hline ELF & \\
\hline
\end{tabular}

Table 6 shows Station "Adptador3" as the station that mostly constraints the system. However, production stations that did not present a high percentage when using the "Shifting Bottleneck" method were responsible for a reasonable percentage of "Sole Bottleneck". Therefore, even if the figures obtained from methods 1,4 and 5 look alike, the shifting bottleneck method (5) has higher "resolution" since the standard deviation regarding the major bottleneck and the others is higher (see table 6). So the differentiation between all the bottlenecks is higher with this method, indicating it is the best suitable method in this situation.

These analyses lead to Table 7, which pinpoints strengths and weaknesses of each bottleneck detection method, according to several criteria. This table uses quantitative measures and, therefore, provides a better comparison framework than that on Tanaka, Nakano, and Roser (2002).

The first criterion is data requirements. Since methods 1, 2 and 3 uses data generally present in simulation software reports, no additional effort is needed to collect data. For methods 4 and 5, it is necessary to do some programming on the simulation software and post processing.

Table 5: Comparison of the Methods regarding the complete case study (low fluctuation). Primary Bottleneck is Blow3 and Secondary Bottleneck is Blow1.

\begin{tabular}{|c|c|c|c|c|c|}
\hline Production Station & 1 & 2 & 3 & 4 & 5 \\
\hline Mixture1 & 0.00 & - & - & 0.00 & 0.00 \\
\hline SetUP1 & 0.00 & 0.00 & 0.00 & 0.28 & 0.00 \\
\hline Blow9 & 84.85 & 12.61 & 18.28 & 88.66 & 0.00 \\
\hline P100 & 11.85 & 0.02 & 0.05 & 12.46 & 0.00 \\
\hline Transport 1 & 0.63 & 12.43 & 22.09 & 1.47 & 0.00 \\
\hline Tank A & 9.43 & - & - & 10.20 & 0.00 \\
\hline Tank B & 4.91 & - & - & 5.75 & 0.00 \\
\hline Promaq Serac & 5.63 & 0.00 & 0.02 & 6.17 & 0.00 \\
\hline SetUP 2 & 0.00 & 0.01 & 0.01 & 0.11 & 0.00 \\
\hline Blow3 & 93.08 & 12.67 & 27.07 & 95.80 & 95.66 \\
\hline Dubuit5_6 & 0.00 & 0.03 & 0.09 & 0.00 & 0.00 \\
\hline Transport 2 & 0.13 & 2.69 & 6.11 & 1.26 & 0.00 \\
\hline Tank F & 2.73 & - & - & 3.10 & 0.00 \\
\hline Adptador 3 & 13.69 & 0.05 & 0.25 & 13.97 & 0.00 \\
\hline Mixture 2 & 0.00 & - & - & 0.00 & 0.00 \\
\hline SetUP 3 & 0.00 & 0.00 & 0.00 & 0.18 & 0.00 \\
\hline Mixture 3 & 0.00 & - & - & 0.00 & 0.00 \\
\hline Transport 3 & 0.11 & 2.94 & 16.61 & 0.42 & 0.00 \\
\hline Tank V & 2.95 & - & - & 3.13 & 0.00 \\
\hline P04 & 5.37 & - & - & 5.69 & 0.00 \\
\hline SetUP 4 & 0.00 & 0.00 & 0.00 & 0.21 & 0.00 \\
\hline Mixture 4 & 0.00 & - & - & 0.00 & 0.00 \\
\hline Blow 8 & 16.63 & 0.23 & - & 17.54 & 0.00 \\
\hline Screener09 & 11.67 & 0.00 & 0.02 & 11.48 & 0.00 \\
\hline Transport 4 & 0.23 & 0.81 & 3.41 & 0.60 & 0.00 \\
\hline SetUP 5 & 0.00 & 0.01 & 0.01 & 0.14 & 0.00 \\
\hline Mixture 5 & 0.00 & - & - & 0.00 & 0.00 \\
\hline Serimatic1_2 & 0.00 & 0.18 & 0.26 & 0.00 & 0.00 \\
\hline Transport 5 & 0.32 & 13.18 & 20.14 & 1.23 & 0.00 \\
\hline Tank O & 2.23 & - & - & 2.87 & 0.00 \\
\hline Tank P & 1.09 & - & - & 1.40 & 0.00 \\
\hline Adptador 2 & 4.81 & 0.03 & 0.04 & 4.38 & 0.00 \\
\hline SetUP 6 & 0.00 & 0.00 & 0.01 & 0.11 & 0.00 \\
\hline Mixture 6 & 0.00 & - & - & 0.00 & 0.00 \\
\hline Blow 7 & 53.40 & 9.24 & 10.43 & 54.97 & 0.00 \\
\hline Transport 6 & 0.41 & 8.33 & 21.40 & 0.88 & 0.00 \\
\hline SetUP 7 & 0.00 & 0.00 & 0.00 & 0.14 & 0.00 \\
\hline Mixture 7 & 0.00 & - & - & 0.00 & 0.00 \\
\hline Transport 7 & 0.35 & 3.19 & 5.04 & 0.79 & 0.00 \\
\hline SetUP 8 & 0.00 & 0.00 & 0.00 & 0.18 & 0.00 \\
\hline Mixture 8 & 0.00 & - & - & 0.00 & 0.00 \\
\hline Blow 1 & 89.36 & 2.76 & 10.24 & 92.09 & 18.59 \\
\hline Dbuit5_6_eSerimatic1_2 & 0.00 & 0.05 & 0.10 & 0.00 & 0.00 \\
\hline Transport 8 & 0.06 & 6.77 & 26.39 & 0.60 & 0.00 \\
\hline Tank H & 0.75 & - & - & 0.67 & 0.00 \\
\hline SetUP 9 & 0.00 & 0.00 & 0.00 & 0.35 & 0.00 \\
\hline Mixture 9 & 0.00 & - & - & 0.00 & 0.00 \\
\hline
\end{tabular}

The second criterion is primary bottleneck detection. The method that identifies the main bottleneck with the highest precision is the Shifting Bottleneck Method.

Third criterion relates to secondary bottlenecks detection. It shows all methods but those based on queue size (methods 2 and 3 ) are able to detect secondary bottlenecks. 
Table 6: Comparison of the Methods regarding the complete case study (low fluctuation). Primary Botlleneck is Adptador3.

\begin{tabular}{|l|c|c|c|c|c|}
\hline $\begin{array}{c}\text { Production Sta- } \\
\text { tion }\end{array}$ & $\mathbf{1}$ & $\mathbf{2}$ & $\mathbf{3}$ & $\mathbf{4}$ & $\mathbf{5}$ \\
\hline Transport 1 & 0.63 & 2.69 & 22.09 & 0.80 & 0.71 \\
\hline Tank A & 9.43 & - & - & 10.85 & 11.03 \\
\hline Tank B & 4.92 & - & - & 5.72 & 4.90 \\
\hline Promaq_Serac & 5.63 & 0.00 & 0.02 & 5.67 & 2.07 \\
\hline Transport 2 & 0.13 & 0.00 & 6.11 & 0.32 & 0.09 \\
\hline Tank F & 2.73 & - & - & 3.71 & 2.36 \\
\hline Adptador3 & $\mathbf{1 3 . 6 9}$ & $\mathbf{0 . 0 5}$ & $\mathbf{0 . 2 4}$ & $\mathbf{1 3 . 7 5}$ & $\mathbf{1 6 . 1 3}$ \\
\hline Transport 3 & 0.11 & 2.94 & 16.61 & 0.11 & 0.06 \\
\hline Tank V & 2.83 & - & - & 3.13 & 3.30 \\
\hline P04 & 5.37 & - & - & 5.43 & 6.21 \\
\hline Transport 4 & 0.23 & 0.81 & 3.41 & 0.29 & 0.34 \\
\hline Transport 5 & 0.32 & 0.00 & 20.14 & 0.48 & 0.33 \\
\hline Tank O & 2.23 & - & - & 2.87 & 3.34 \\
\hline Tank P & 1.09 & - & - & 1.40 & 0.83 \\
\hline Adptador2 & 4.81 & 0.03 & 0.04 & 4.82 & 4.03 \\
\hline Transport 6 & 0.41 & 8.33 & 21.40 & 0.50 & 0.58 \\
\hline Transport 7 & 0.35 & 3.19 & 5.04 & 0.39 & 0.32 \\
\hline Transport 8 & 0.06 & 6.77 & 26.39 & 0.15 & 0.04 \\
\hline Tank H & 0.74 & - & - & 1.04 & 0.79 \\
\hline Transport 9 & 0.07 & 2.42 & 6.93 & 0.15 & 0.04 \\
\hline
\end{tabular}

Table 7: Overall Comparison of the methods

\begin{tabular}{|c|c|c|c|c|}
\hline Criteria & 1 & 2 and 3 & 4 & 5 \\
\hline $\begin{array}{l}\text { Data } \\
\text { Requirement }\end{array}$ & $\begin{array}{l}\text { Automatic } \\
\text { Generated } \\
\text { by } \\
\text { Simulation }\end{array}$ & $\begin{array}{l}\text { Automatic } \\
\text { Generated } \\
\text { by } \\
\text { Simulation }\end{array}$ & $\begin{array}{l}\text { Active } \\
\text { time is } \\
\text { generated } \\
\text { by Code } \\
\text { (Visual } \\
\text { Logic } \\
\text { Function) } \\
\text { and Post } \\
\text { Process- } \\
\text { ing in } \\
\text { Excel }\end{array}$ & $\begin{array}{l}\text { All lines } \\
\text { of Active } \\
\text { time and } \\
\text { non-active } \\
\text { time is } \\
\text { generated } \\
\text { by code } \\
\text { (Visual } \\
\text { Logic) } \\
\text { and Post } \\
\text { Process- } \\
\text { ing in Ex- } \\
\text { cel }\end{array}$ \\
\hline $\begin{array}{l}\text { Primary } \\
\text { Bottleneck } \\
\text { Detenction }\end{array}$ & $\begin{array}{l}\text { Low Dif- } \\
\text { ferentia- } \\
\text { tion be- } \\
\text { tween } \\
\text { primary } \\
\text { and sec- } \\
\text { ondary } \\
\text { bottleneck } \\
\text { (less than } \\
5 \% \text { ) }\end{array}$ & $\begin{array}{l}\text { Low Dif- } \\
\text { ferentia- } \\
\text { tion be- } \\
\text { tween } \\
\text { primary } \\
\text { and sec- } \\
\text { ondary } \\
\text { bottleneck } \\
\text { (less than } \\
5 \% \text { ) }\end{array}$ & $\begin{array}{l}\text { Low Dif- } \\
\text { ferentia- } \\
\text { tion Be- } \\
\text { tween } \\
\text { primary } \\
\text { and sec- } \\
\text { ondary } \\
\text { bottleneck } \\
\text { (less than } \\
5 \% \text { ) }\end{array}$ & $\begin{array}{l}\text { Good dif- } \\
\text { ferentia- } \\
\text { tion of the } \\
\text { primary } \\
\text { and sec- } \\
\text { ondary } \\
\text { bottleneck } \\
\text { (greater } \\
\text { than } 77 \% \text { ) }\end{array}$ \\
\hline $\begin{array}{l}\text { Secondary } \\
\text { Bottleneck } \\
\text { Detection }\end{array}$ & $\begin{array}{l}1 \\
\text { secondary } \\
\text { botleneck }\end{array}$ & $\begin{array}{l}\text { Unable to } \\
\text { Detect }\end{array}$ & $\begin{array}{l}1 \\
\text { secondary } \\
\text { botleneck }\end{array}$ & $\begin{array}{l}1 \\
\text { secondary } \\
\text { botleneck }\end{array}$ \\
\hline $\begin{array}{l}\text { Non } \\
\text { Bottlenecks } \\
\text { Detenction }\end{array}$ & $\begin{array}{l}\text { No } \\
\text { Identifica- } \\
\text { ble }\end{array}$ & $\begin{array}{l}\text { No } \\
\text { Identifica- } \\
\text { ble }\end{array}$ & $\begin{array}{l}\text { No } \\
\text { Identifica- } \\
\text { ble }\end{array}$ & $\begin{array}{l}\text { Detectable } \\
\text { for each } \\
\text { station }\end{array}$ \\
\hline $\begin{array}{l}\text { Methods } \\
\text { Implementa- } \\
\text { tion) }\end{array}$ & Easy & Easy & Medium & High \\
\hline
\end{tabular}

The fourth criterion refers to detection of non bottlenecks; which can be accomplished only by method 5 .

The fifth criterion is the degree of difficulty in implement and analyzes results. Since methods 4 and 5 are non-standard in simulation software, they are harder to implement. In fact the major drawback of method number 5 is the implementation time. To provide an order of magnitude of processing time it took almost five hours to perform all the calculations of whole case study with Pentium IV - 667 $\mathrm{MHz}-512 \mathrm{Mb}$.

\section{CONCLUSIONS}

This work discussed a method for aiding the choice of which method to apply for bottleneck detection. The method was applied in a real process of a chemical industry with the aid of a simulation model. The proposed method is suitable for application even on systems with shifting bottlenecks.

A numeric factor, called "ELF", was introduced. ELF higher than 0.5 suggests the application of queue size methods (1,2 or 3), although they are based on the assumption of infinite queues, which may not hold. For lower ELF values, method 5 should be used, although methods 1 and 4 could be applied. The method was validated in a real world case study.

A Simul8 Component to implement methods 4,5 is at <http://www.simul8.com/components/>.

As future works we can cite the improvement of the methods 4 and 5 calculations in order to minimize the processing time and an online real-time implementation of these methods within a supervisory system.

\section{REFERENCES}

Aneja, Y.P, and A.P. Punnen. 1999. Multiple Bottleneck assignment problems. European Journal of Operational Research 112:167-173.

Lima, E.P., L. Chwif, and M.R.P Barretto. 2007. O uso da Simulação de eventos discretos como ferramenta de apoio na detecção de gargalos nos sistemas de produção. In Proceedings of the XIV SIMPEP BRAZIL. Portuguese.

Goldratt, E. 1992. The Goal: A Process of Ongoing Improvement. North River Press.

Grosfeld-Nir, A. 1995. Single Bottleneck systems with proportional expected yields and rigid demand. European Journal of Operational Research 80:297-307.

Roser, C., M. Nakano, and M. Tanaka. 2002. Shifting Bottleneck Detection. In Proceedings of the 2002 Winter Simulation Conference, ed. E. Yücesan, C.-H. Chen, J. L. Snowdon, and J. M. Charnes, 1079-1086. San Diego, CA, USA.

Roser, C., M. Nakano, and M. Tanaka. 2003. Comparison of Bottleneck Detection Methods for AGV Systems. In Proceedings of the 2003 Winter Simulation Conference, ed. S. Chick, P. J. Sánchez, D. Ferrin, and D. J. Morrice, 1192-1198. The Fairmont New Orleans, New Orleans, LA. 


\section{AUTHOR BIOGRAPHIES}

ELISEU P. LIMA graduated in Mechanical Technology (Mechanical Precision Specialization) in 1994 at the FATEC of Sao Paulo and achieved his M.Sc. degree in 2007 from The University of Mauá He specialized in Industrial Administration and System Analysis in 1996 and 1998. Msc. Lima also teaches graduate disciplines at the Drummond College, as well as being the System Consultant of TELEFONICA OF BRAZIL. His research interests include manufacturing simulation and optimization. His e-mail is <eliseu.lima@telefonica.com.br>.

LEONARDO CHWIF graduated in Mechanical Engineering (Mechatronic Specialization) in 1992 at the University of Sao Paulo and achieved his M.Sc. degree in 1994 and his Ph.D. in Simulation in 1999 from the same University. He spent a session at Brunel University as a research visitor at the Centre for Applied Simulation Modelling. Upon graduation Dr. Chwif joined the Brazilian branch of Mercedes- Benz truck manufacturer and then he joined the Brazilian branch of Whirlpool Corporation. Currently he is C.E.O of Simulate Simulation Technology. Dr. Chwif also teaches undergraduate and graduate disciplines on simulation at Mauá School of Engineering and at the University of Sao Paulo. His email address is <leonardo.chwif@maua.br>.

MARCOS RIBEIRO PEREIRA BARRETTO graduated in Electronic Engineering in 1983. He got his M.Sc. degree in 1988 and his Ph.D. in 1993, both from the University of Sao Paulo. He is a professor and researcher within Mechatronics Department at University of Sao Paulo. His email is <mrpbarre@usp.br>. 